\title{
Ujaran kebencian netizen Indonesia dalam kolom komentar Instagram selebgram Indonesia: Sebuah kajian linguistik forensik
}

\author{
Febry Ramadani S \\ UIN Sunan Kalijaga, Indonesia \\ Correspondence: febryramadanis@gmail.com
}

\begin{abstract}
This research aims to analyze hate speech of Indonesian netizens in Rahmawati Kekeyi Putri Cantikka's Instagram comment column were analyzed using forensic linguistic analysis. The research method is qualitative using a forensic linguistic approach. Data collection was obtained by observing and analyzing the evidence of language crimes in the form of hate speech of Indonesian netizens in the Rahmawati Kekeyi Putri Cantikka Instagram comment column. The results revealed 15 netizens' utterances from 22 analyzed data could be said to be valid and then said to be utterances of hatred, as stated in article 27 paragraph (3) juncto Article 45 paragraph (1) The Law of Republic Indonesia 9/2016 concerning Limitation of Law 11/2008 concerning Electronic Information and Transactions (ITE).
\end{abstract}

Keywords: hate speech, Instagram social media, forensic linguistics.

\section{Pendahuluan}

Teknologi informasi dan komunikasi kini tengah berkembang sangat pesat, hal ini ditunjukkan melalui hadirnya smartphone dan jaringan internet ditengah masyarakat. Pemanfaatan sosial media seperti WhatsApp, Line, Facebook, Twitter, Youtube, Instagram, dan lain-lain menjadi sebuah revolusi hebat dalam komunikasi di era modern. Keluasan fasilitas untuk berkomunikasi melalui jaringan internet membuat media sosial menjadi sebuah forum terbuka dan bebas berbicara antar pengikutnya. Melalui media sosial seseorang bebas berkomunikasi dengan orang lain, baik dalam bentuk update status, 
berkomentar, mengkritik, bahkan menghujat orang lain. Seseorang dengan mudahnya dapat berpartisipasi, berbagi, dan mengisi dalam forum di media sosial masing-masing.

Adapun bahasa ialah sebuah instrumen untuk berkomunikasi, baik dengan lisan maupun tulisan. Bahasa yang dituturkan oleh seseorang mengandung nilai dan norma didalamnya. Maka dalam setiap tuturan penting bagi setiap orang untuk menyaring bahasa yang akan dipakai sesuai dengan situasi, kondisi, dan mempertimbangkan nilai-nilai serta norma sosial. Endang mengatakan bahwa seiring dengan perkembagan teknologi informasi dan komunikasi, mendorong munculnya kasus kejahatan berbahasa, misalnya hasutan, hujatan, ancaman, penyebaran berita bohong (hoax), penyuapan, konspirasi, sumpah palsu, pencemaran nama baik termasuk fitnah dan penghinaan yang menjadi perhatian masyarakat Indonesia. Sebuah unggahan atau status seseorang di media sosial dapat berdampak hukum jika terdapat pihak lain yang merasa dirugikan atas unggahan tersebut. Sama halnya dengan pesan-pesan yang dikirimkan melalui media sosial yang didalamnya dianggap memuat unsur kejahatan berbahasa juga dapat dikenai tuntutan dan gugatan secara hukum. (Sholihatin, 2019, hlm. 2).

Demikian halnya ujaran kebencian bukanlah sebuah hal yang baru, melainkan sudah ada dalam media tradisional sebelum terjadinya perkembangan teknologi yang amat pesat seperti sekarang. Sebuah ujaran ataupun tuturan yang mendorong kebencian yang secara konseptual adalah fenomena kontemporer sudah sering ditemukan dalam teks-teks media tradisional sejak lama dan dengan mudah dapat diproduksi dan diedarkan di media baru yang memiliki sejarah baru. (Koncavar, 2013, hlm. 675).

Ujaran Kebencian merupakan sebuah aktivitas komunikasi yang dikerjakan oleh seorang individu atau kelompok kepada individu atau kelompok lainnya dalam bentuk provokasi, hasutan, ataupun hinaan yang meliputi berbagai sudut, seperti warna kulit, ras, etnis, agama, dan lain sebagainya. (Syarif, 2019, hlm. 123). James mengatakan bahwa pada umunya ujaran kebencian dengan cepat disebarkan melalui media sosial sehingga memunculkan informasi yang samar-samar dan keliru, yang pada akhirnya akan memunculkan dugaan yang salah. (Bank, 2011, hlm. 239)

Koncavar menambahkan bahwa ujaran kebencian merupakan perkataan yang mendorong kebencian, yang dapat digambarkan sebagai suatu hal yang rasis, diskriminatif agama, xenofobia, homofobik, transphobik, heteroseks, nasionalis etnis, kesadaran status sosial, kesadaran status ekonomi, dan diskriminasi menurut kecacatan mereka, dan lain sebagainya secara terangterangan ataupun tersembunyi. (Koncavar, 2013: 675). Sedangkan, Dewan Komite Menteri Eropa mendefinisikan ujaran kebencian harus dipahami sebagai segala sesuatu yang mencakup segala bentuk ekspresi yang memperluas, memprovokasi, memublikasikan atau membenarkan kebencian rasial, 
xenophobia, anti-Semitisme atau segala bentuk kebencian lainnya berdasarkan intoleransi, termasuk intoleransi diekspresikan oleh nasionalisme agresif dan etnosentrisme, diskriminasi, dan permusuhan terhadap minoritas, migran dan orang-orang asal imigran. (Koncavar, 2013, hlm. 679).

Dengan demikian, dapat disimpulkan bahwa ujaran kebencian merupakan tindakan kejahatan berbahasa yang dilakukan dengan menyiarkan pendapat untuk mencari pengikut atau dukungan agar seseorang ikut membenci orang lain atau sesuatu yang menjadi target. Seseorang yang mengungkapkan ujaran kebencian lantaran beragam faktor, salah satu contohnya disebabkan orang tersebut berbeda pendapat dan tidak sedang berada dipihak orang yang diserang dengan ujaran kebencian tersebut.

Adapun kemajuan teknologi yang ditandai dengan munculnya fasilitas jaringan media sosial di era digital ini membuat kebencian semakin mudah untuk disebar luaskan, karena media sosial merupakan ruang publik yang interaktif. Binark (dalam Koncavar, 2013, hlm. 675) menambahkan dengan menyatakan bahwa jumlah situs web rasis mengalami peningkatan di Amerika Serikat dan Eropa setelah penyebaran internet. Situasi ini tidaklah jauh berbeda dengan yang terjadi di Indonesia. Semenjak munculnya ruang publik yang interaktif seperti media sosial, banyak pemberitahuan mengenai kemunculan kejahatan berbahasa berupa ujaran kebencian.

Oleh karena itu, pemerintah akhirnya mengeluarkan UU No. 11 Tahun 2008 tentang Informasi dan Transaksi Elektronik (UU ITE) yang akhirnya diperbarui menjadi UU Republik Indonesia No. 19 Tahun 2016 tentang perubahan atas UU No. 11 Tahun 2008 tentang ITE untuk merespon tindakan kejahatan berbahasa melalui media sosial elektronik seperti WhatsApp, Line, Twitter, Facebook, Youtube, Instagram, dan lain-lain. Selain itu, kejahatan berbahasa yang dilakukan melalui media elektronik seperti ucapan langsung, surat, tulisan di dinding, baliho, spanduk, poster dan lain sebagainya diatur didalam Kitab Undang-Undang Hukum Pidana (KUHP).

Sementara itu, ujaran kebencian di Indonesia disusun dalam Pasal 156 dan 157 KUHP, yang didalamnya menata tindak pidana penebar kebencian, perselisihan, dan penghinaan. UU Nomor 12 Tahun 2005 tentang Pengesahan Konvenan Internasioal tentang Hak-Hak Sipil dan Politik, UU Nomor 40 Tahun 2008 tentang Penghapusan Diskriminasi Ras dan Etnis, Pasal 4 huruf b melarang seseorang menampakkan perasaan benci atau kebencian kepada orang lain karena adanya perbedaan pada ras dan etnis, baik dalam bentuk tulisan maupun gambar, pidato ataupun penggunaan simbol-simbol yang dilakukan di depan publik, UU RI Nomor 19 Tahun 2016 tentang Perubahan atas UU No. 11 Tahun 2008 tentang ITE juga memuat tentang pelanggaran ujaran kebencian seperti yang dimaksudkan dalam Pasal 28 ayat 2 dan Pasal 45 ayat 2, UU No. 9 Tahun 1998 tentang Kemerdekaan Menyampaikan Pendapat di depan publik juga memuat tentang tindak pidana ujaran kebencian, 
terkhusus pada Pasal 6 huruf E dengan sanksi pembubaran atau pemberhentian orasi.

Saat ini, salah satu dari banyaknya media sosial yang paling sering digunakan dan sangat disenangi oleh penduduk Indonesia adalah Instagram. Melalui Instagram netizen dapat membuat ruang untuk menuliskan komentar apapun terhadap status atau unggahan foto dan video yang diunggah oleh sang pengguna. Maraknya penggunaan Instagram sebagai media sosial selain dapat memberikan hiburan dan kemudahan bagi penggunanya, Instagram juga mampu mendorong timbulnya permasalahan. Nurul mengatakan salah satu hasil penelitian yang ditemukan adalah hasil penuturan yang terduga menjadi ujaran kebencian yang banyak dipakai oleh netizen Indonesia di kolom komentar akun Instagram Selebgram Indonesia. Seorang Netizen yang selalu memberikan komentar negatif hingga mengeluarkan beragam ujaran kebencian pada kolom komentar akun Instagram seorang Selebgram umunya dinamakan sebagai seorang haters.

Menjadi suatu hal yang lazim bagi seorang public figure ketika memiliki fans dan haters yang tidak pernah terlepas dari kehidupannya. Haters adalah sebutan bagi seseorang atau kelompok yang berfokus untuk mengkritik kehidupan seseorang, Namun, hal ini menjadi berbahaya ketika seseorang mengungkapkan kebencian secara berlebihan dan mengekspresikan kebencian tersebut di media sosial. Hal ini tentu akan berdampak bagi penutur dan mitra tuturnya, bahkan berdampak pada hukum.

Eddy berdasarkan hasil penelitiannya mengatakan bahwa seringkali ujaran kebencian suatu peristiwa yang akhirnya membentuk objek pembangunan opini publik merupakan suatu hal yang bersifat adu domba dalam kehidupan masyarakat, bahkan berpeluang dapat melahirkan konflik horizontal dalam realita kehidupan masyarakat. (Syarif, 2019, hlm. 123). Misalnya dalam kutipan yang didapatkan dari kolom komentar pada akun Instagram seorang public figure @rahmawatikekeyiputricantikka23 yang diduga merupakan ujaran kebencian dari para netizen Indonesia.

"Dasar orang sok PD Luhh... anda pikir senyuman lo bagus? Nggak sama sekali,,”.@rohmaaah_15.

"Iiihhhhh mukanya kayak Pork!!! (disertai dengan emotikon babi)”. @kekeyirakus.

"Cepet mati lu anjeng”. @pandaaamerah.

"Duh macam tai kucing posemu tuh". @lusianadevii.

"Emaknya ngidam curut”. @andihrtd_.

Berbagai ujaran di atas diduga dapat mengandung kebencian yang diungkapkan netizen Indonesia dalam kolom komentar akun Instagram seorang Selebgram Indonesia bernama Rahmawati Kekeyi Putri Cantikka yang lebih dikenal dengan sebutan Kekeyi ketika ia menggugah foto dirinya ke Instagram. Jika dilihat berbagai komentar di atas dapat dianggap sebagai penghinaan 
lantaran secara langsung dapat menyerang harga diri dan kondisi mental seorang public figure, apalagi hal tersebut dilakukan di ruang publik dan jumlah pengikut akun@rahmawatikekeyiputricantikka23 yang mencapai $787 \mathrm{~K}$ terbilang sangat banyak memungkinkan netizen bebas utuk berkomentar atas seluruh tindakan ataupun unggahan artis yang diikutinya. Image Kekeyi menjadi rusak dan tidak baik dimata publik akibat banyaknya komentar negatif dari netizen Indonesia di akun Instagram miliknya. Munculnya komentar negatif disebabkan oleh reaksi netizen Indonesia setelah menonton berbagai vlog dan postingan yang diunggah Kekeyi.

Analisis kajian linguistik forensik pada bidang ini sangat cocok dimanfaatkan untuk menangani sebuah kasus dan menerangkan kasus penggunaan bahasa serta hubungannya dengan hukum. Olsson mengatakan linguistik forensik merupakan hubungan antara bahasa, tindak kriminal, dan hukum. Dimana didalamnya meliputi penegak hukum, permasalahan hukum, perundang-undangan, perselisihan, proses hukum, bahkan perselisihan yang mampu mengikutsertakan sejumlah pengingkaran hukum yang diarahkan untuk memperoleh penuntasan hukum. (Olsson, 2008, hlm. 3). Dalam hal ini, dapat dikatakan bahwa linguistik forensik tidak hanya berfokus pada kasus yang telah diangkat ke persidangan, akan tetapi berfokus juga pada kasus ataupun masalah yang telah melanggar nilai dan norma sosial pada masyarakat seperti kasus penyebaran berita bohong, peringatan, penghinaan, dan lain sebagainya meskipun belum diangkat ke persidangan. Kejahatan yang terbentuk melalui bahasa merupakan kejahatan yang dapat dipelajari menggunakan sudut pandang linguistik. Ujaran kebencian dapat diungkapkan via beragam media, termasuk media sosial. Berbagai komentar negatif yang memojokkan seorang artis di media sosial sebenarnya tidak bisa dikatakan ujaran kebencian. Akan tetapi, melalui dukungan analisis linguistik suatu ujaran bisa dibuktikan kebenarannya merupakan ujaran kebencian yang memiliki dampak hukum.

Hasil penelitian Ningrum, Suryadi, dan Dian mengemukakan bahwa bentuk ujaran kebencian yang seringkali diungkapkan oleh netizen Indonesia untuk merespon informasi di kolom komentar berdasarkan masing-masing konteks tuturan yang bersangkutan adalah bentuk penghinaan sebesar 16,89\%, disusul dengan bentuk ujaran kebencian dalam kategori memprovokasi sebanyak $6,12 \%$, menghasut sebanyak $1,36 \%$, pencemaran nama baik sebanyak 0,90\%, dan kategori perbuatan tidak menyenangkan termasuk yang paling sedikit ditemukan sebesar 0,56\%. (Ningrum, Suryadi, \& Wardhana, n.d., 2918, hlm. 251).

Dengan demikian, salah satu kajian linguistik forensik yang sangat menarik dan menjadi penting bagi peneliti untuk dikaji adalah kajian terhadap ujaran kebencian netizen di media sosial mengingat ujaran kebencian di Instagram menjadi kasus yang akhir-akhir ini paling sering terjadi. Melalui 
penelitian ini, ujaran di media sosial Instagram yang dianggap memiliki potensi berakibat hukum akan diselidiki menggunakan teori-teori pragmatik yang dijadikan sebagai pisau analisis data. Dengan ramainya pemakaian ujaran kebencian di media sosial semestinya para peneliti bisa menjadikannya sebagai ladang analisis, khususnya cabang ilmu bahasa atau linguistik.

Penelitian ini berfokus pada komentar netizen Indonesia di akun Instagram public figure bernama Kekeyi yang kini sedang trending di Indonesia karena vlog dan unggahannya mengundang banyak perhatian dari netizen Indonesia. Dalam konteks forensik, fokus analisisnya ialah pengetahuan dan tafsiran bahasa dalam kolom komentar Instagram Kekeyi. Adapun data yang dianalisis dalam penelitian ini adalah data yang didapatkan melalui media sosial Instagram. Adapun tujuan dari penelitian ini adalah untuk membahas secara mendalam mengenai ujaran kebencian netizen indonesia pada kolom komentar Instagram Rahmawati Kekeyi Putri Cantikka yang dikaji menggunakan analisis linguistik forensik. Hasil penelitian ini diharapkan dapat dijadikan sebagai tambahan pengetahuan dan wawasan bagi para netizen Indonesia agar menjadi lebih bijak ketika berbahasa di dunia maya.

\section{Metode}

Penelitian ini ialah jenis penelitian kualitatif yang menggunakan pendekatan linguistik forensik. Dimana pengumpulan data didapatkan dari hasil melakukan pengamatan dan menganalisis pembuktian kejahatan berbahasa dalam bentuk ujaran kebencian para netizen Indonesia pada kolom komentar Instagram Rahmawati Kekeyi Putri Cantikka dengan akun @rahmawatikekeyiputricantikka23. Penelitian ini menerapkan metode deskriptif. Peneliti menganalisis data dengan beberapa tahapan, diantaranya pengumpulan data pada instagram kekeyi, mereduksi data, penyajian data, menganalisis data berdasarkan prinsip (UU ITE No. 11 Tahun 2008 tentang Informasi dan Transaksi Elektronik yang kemudian diperbarui dengan UndangUndang Republik Indonesia No. 19 Tahun 2016). Sehingga, peneliti tidak sekedar menyajikan berbagai fakta kepada pembaca, melainkan juga interpretasi fenomena yang sedang diteliti.

Dalam penelitian ini terdapat dua sumber data, yaitu sumber data primer dan sumber data sekunder. Sumber data primer dalam penelitian ini ialah media sosial Instagram yang dapat diakses oleh semua pihak, berupa teks yang diambil melalui penelusuran secara online pada kolom komentar instagram kekeyi. Sementara sumber data sekunder dalam penelitian ini ialah beragam buku dan artikel jurnal terkait tema penelitian.

Adapun fokus pembahasan dalam penelitian ini adalah implikatur pada ujaran para netizen Indonesia di kolom komentar Instagram Kekeyi, daya ilokusi ujaran, dan tingkat validitas ujaran para netizen Indonesia di kolom komentar Instagram Kekeyi yang disangka melahirkan bentuk tindakan 
penghinaan dan ungkapan kebencian seperti yang disebutkan dalam Pasal 27 ayat (3) juncto Pasal 45 ayat (1) UU RI No. 9 Tahun 2016 tentang pembatasan UU No. 11 Tahun 2008 mengenai Informasi dan Transaksi Elektronik (ITE).

\section{Hasil dan Pembahasan}

\section{Implikatur Ujaran Netizen Indonesia di Kolom Komentar Instagram Selebgram Indonesia}

Penghinaan

Penghinaan adalah salah satu wujud ujaran kebencian yang bertujuan untuk menjatuhkan, mencela, menistakan atau melecehkan seseorang. Biasanya penghinaan dilakukan dengan cara merendahkan fisik, warna kulit, suku, ras, agama, menyamakan seseorang dengan binatang, dan lain sebagainya. Selain itu, penghinaan dapat juga berbentuk tuduhan kepada seseorang bahwa ia melakukan suatu perbuatan yang belum terbukti kebenarannya. Penghinaan dengan menuduh seseorang melakukan perbuatan masuk dalam Pasal 310 dan 311 KUHP. Sedangkan penghinaan ringan berupa makian masuk dalam Pasal 315 KUHP. Berikut adalah tabel analisis komentar netizen Indonesia di kolom komentar Instagram Rahmawati Kekeyi Putri Cantikka yang terdeteksi mengandung ujaran kebencian penghinaan:

Tabel 1 Analisis Implikatur Penghinaan di Kolom Komentar Instagram @rahmawatikekeyiputricantikka23

\begin{tabular}{|c|c|c|c|}
\hline No & Akun & Komentar & Analisis Implikatur \\
\hline & @kekeyirakus & $\begin{array}{l}\text { Iiihhhhh mukanya } \\
\text { kayak Pork !!! }\end{array}$ & $\begin{array}{l}\text { Komentar "Iiihhhhh mukanya kayak } \\
\text { Pork !!!" pada ujaran disamping } \\
\text { teridentifikasi sebagai ujaran } \\
\text { kebencian penghinaan. Mukanya } \\
\text { kayak Pork adalah frasa yang } \\
\text { menunjukkan penghinaan terhadap } \\
\text { fisik Kekeyi. Kata pork secara } \\
\text { heuristik merupakan kata benda } \\
\text { yang berasal dari bahasa Inggris. } \\
\text { Kata pork dalam bahasa Indonesia } \\
\text { memiliki arti babi. Babi menurut } \\
\text { KBBI ialah hewan menyusui yang } \\
\text { memiliki moncong mancung, } \\
\text { memiliki kulit yang rimbun, dan } \\
\text { memiliki bulu yang keras. Kata babi } \\
\text { biasanya digunakan sebagai umpatan } \\
\text { yang sangat kasar di kalangan } \\
\text { masyarakat Indonesia. Analisis } \\
\text { hermeneutik pada kalimat mukanya } \\
\text { kayak Pork memiliki makna netizen } \\
\text { ini berasumsi bahwa Kekeyi memiliki } \\
\text { wajah yang sama dengan wujud } \\
\text { binatang babi, yang mana binatang } \\
\text { babi selalu dikaitkan dengan konteks }\end{array}$ \\
\hline
\end{tabular}




\begin{tabular}{|c|c|c|c|}
\hline & & & $\begin{array}{l}\text { binatang yang menjijikkan bagi } \\
\text { sebagian orang, kotor, jorok dan } \\
\text { dikenal sebagai binatang haram. }\end{array}$ \\
\hline 2. & @emma_mochtar & $\begin{array}{l}\text { Body lu yg mekar! } \\
\text { Dasar gentong }\end{array}$ & $\begin{array}{l}\text { Komentar "Body lu yg mekar! Dasar } \\
\text { gentong" pada ujaran disamping } \\
\text { teridentifikasi sebagai ujaran } \\
\text { kebencian penghinaan. Body lu yg } \\
\text { mekar! adalah frasa yang } \\
\text { menunjukkan penghinaan terhadap } \\
\text { fisik Kekeyi. Kata mekar secara } \\
\text { heuristik merupakan kata sifat yang } \\
\text { dalam KBBI memiliki arti } \\
\text { berkembang, menjadi besar, dan } \\
\text { gembung. Analisis hermeneutik pada } \\
\text { kalimat body lu yg mekar! Dasar } \\
\text { gentong ini memiliki makna netizen } \\
\text { mengatakan bahwa Kekeyi memiliki } \\
\text { tubuh yang besar dan mengembang } \\
\text { seperti gentong yang identik dengan } \\
\text { tempat penampungan air yang besar. }\end{array}$ \\
\hline 3 . & @itsmaharani26 & $\begin{array}{l}\text { Seperti hidungnya } \\
\text { sahabat yg mekar }\end{array}$ & $\begin{array}{l}\text { Komentar "Seperti hidungnya } \\
\text { sahabat yg mekar! yang dituturkan } \\
\text { seorang netizen saat Kekekyi } \\
\text { mengunggah foto dirinya dengan } \\
\text { caption "Merah2 dulu guys biar } \\
\text { mekar. Lagi membara soalnya. } \\
\text { Hehehehe". Pada ujaran netizen } \\
\text { tersebut teridentifikasi sebagai } \\
\text { ujaran kebencian penghinaan. } \\
\text { Hidungnya sahabat yg mekar } \\
\text { adalah frasa yang menunjukkan } \\
\text { penghinaan terhadap fisik Kekeyi. } \\
\text { Kata mekar secara heuristik } \\
\text { merupakan kata sifat yang dalam } \\
\text { KBBI memiliki arti berkembang, } \\
\text { menjadi besar, dan gembung. } \\
\text { Analisis hermeneutik pada kalimat } \\
\text { Hidungnya sahabat yg mekar ini } \\
\text { memiliki makna netizen mengatakan } \\
\text { bahwa Kekeyi memiliki hidung } \\
\text { dengan lubang hidung yang besar } \\
\text { dan lebar. }\end{array}$ \\
\hline & @putriduta16_ & $\begin{array}{ll}\text { Kyk babi } & \text { dah } \\
\text { mukak lu ihh } & \end{array}$ & $\begin{array}{l}\text { Komentar "Kyk babi dah mukak lu } \\
\text { ihh" pada ujaran disamping } \\
\text { teridentifikasi sebagai ujaran } \\
\text { kebencian penghinaan. Kyk babi dah } \\
\text { mukak lu ihh adalah frasa yang } \\
\text { menunjukkan penghinaan terhadap } \\
\text { fisik, terkhusus pada wajah Kekeyi. } \\
\text { Kata babi menurut KBBI ialah } \\
\text { hewan menyusui yang memiliki } \\
\text { moncong mancung, memiliki kulit } \\
\text { yang rimbun, dan memiliki bulu } \\
\text { yang keras. Kata babi biasanya } \\
\text { digunakan sebagai umpatan yang } \\
\text { sangat kasar di kalangan masyarakat } \\
\text { Indonesia. Analisis hermeneutik } \\
\text { pada kalimat kyk babi dah mukak lu }\end{array}$ \\
\hline
\end{tabular}




\begin{tabular}{|c|c|c|}
\hline & & $\begin{array}{l}\text { memiliki makna netizen ini } \\
\text { berasumsi bahwa Kekeyi memiliki } \\
\text { wajah yang sama dengan wujud } \\
\text { binatang babi, yang memiliki } \\
\text { moncong panjang, yang mana } \\
\text { binatang babi selalu dikaitkan } \\
\text { dengan konteks binatang yang } \\
\text { menjijikkan bagi sebagian orang, } \\
\text { kotor, jorok dan dikenal sebagai } \\
\text { binatang haram. }\end{array}$ \\
\hline @azhari_toatubun & $\begin{array}{l}\text { Woi muka lo nyepet } \\
\text { anjing }\end{array}$ & $\begin{array}{l}\text { Komentar "Woi muka lo nyepet } \\
\text { anjing" pada ujaran disamping } \\
\text { teridentifikasi sebagai ujaran } \\
\text { kebencian penghinaan. Woi muka lo } \\
\text { nyepet anjing adalah frasa yang } \\
\text { menunjukkan penghinaan terhadap } \\
\text { diri seseorang. Kata anjing menurut } \\
\text { KBBI adalah hewan menyusui yang } \\
\text { dipelihara untuk menjaga keamanan } \\
\text { rumah, membantu berburu, dan lain } \\
\text { sebagainya. Kata anjing seringkali } \\
\text { digunakan sebagai umpatan yang } \\
\text { sangat kasar untuk seseorang. } \\
\text { Analisis hermeneutik pada kalimat } \\
\text { Woi muka lo nyepet anjing memiliki } \\
\text { makna netizen ini berasumsi bahwa } \\
\text { Kekeyi sama dengan binatang anjing. }\end{array}$ \\
\hline
\end{tabular}

\section{Rasa Marah dan Kesal}

Rasa marah dan kesal adalah perasaan yang wajar terjadi ketika seseorang merasa tidak nyaman dalam sebuah situasi atau peristiwa. Rasa marah dan kesal adalah satu wujud ujaran kebencian yang bertujuan untuk meluapkan perasaan negatif yang muncul karena kemarahan yang dipendam tidak dapat tersalur. Berikut adalah tabel analisis komentar netizen Indonesia di kolom komentar Instagram Rahmawati Kekeyi Putri Cantikka yang terdeteksi mengandung ujaran kebencian rasa marah dan kesal:

Tabel 2 Analisis Implikatur Rasa Marah dan Kesal di Kolom Komentar Instagram @rahmawatikekeyiputricantikka23

\begin{tabular}{|c|c|c|c|}
\hline No & Akun & Komentar & Analisis Implikatur \\
\hline & @cristahikaru & $\begin{array}{lll}\text { PLIS } & \text { YA } & \text { GW }\end{array}$ & Komentar "PLIS $\quad$ YA $\quad$ GW \\
\hline & & LAGI MAKAN & LAGI MAKAN BNR2 UDAH \\
\hline & & BNR2 UDAH & GA NAPSU SUMPAH INI \\
\hline & & GA NAPSU & GW BENERAN YA GA \\
\hline & & SUMPAH INI & BECANDA" pada ujaran \\
\hline & & GW BENERAN & teridentifikasi \\
\hline & & YA $\quad$ GA & sebagai ujaran kebencian \\
\hline & & BECANDA & rasa marah dan kesal. Frasa \\
\hline & & & GA NAPSU secara heuristik \\
\hline & & & menunjukkan bahwa netizen \\
\hline & & & $\begin{array}{l}\text { tidak memillki selera lag1 } \\
\text { ketika melihat unggahan }\end{array}$ \\
\hline
\end{tabular}




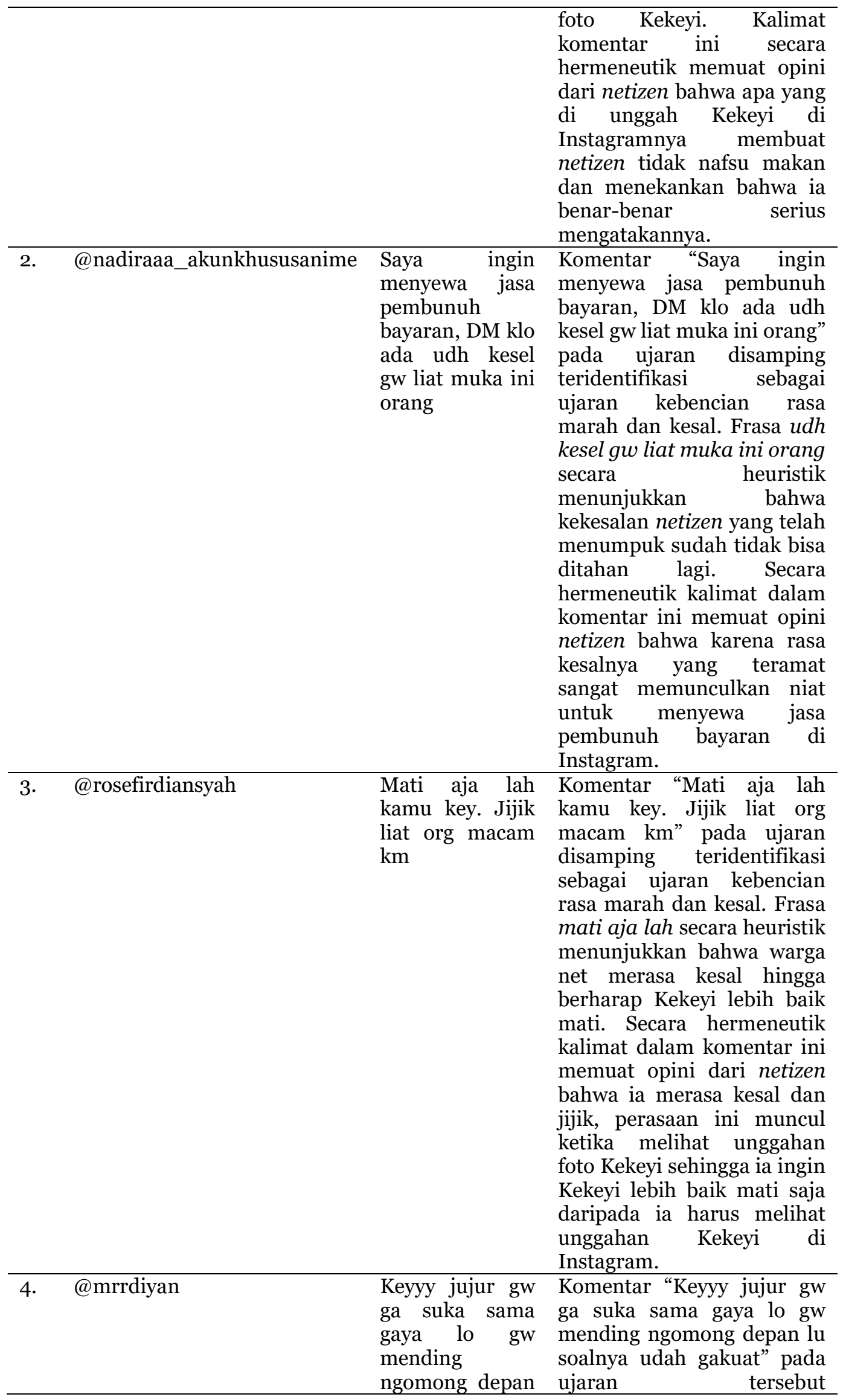




\begin{tabular}{ll}
\hline lu soalnya udah & teridentifikasi sebagai \\
gakuat & ujaran kebencian rasa \\
marah dan kesal. Frasa ga & suka secara heuristik \\
& memiliki arti perasaan tidak \\
& senang hati. Secara \\
& hermeneutik kalimat ini \\
& memuat opini dari netizen \\
bahwa ia merasa amat kesal & terhadap ungahan- \\
unggahan Kekeyi yang telah \\
lama dipendamnya hingga \\
akhirnya ia tidak kuat lagi \\
dan berkomentar bahwa ia \\
berkata jujur tidak \\
menyukai Kekeyi .
\end{tabular}

Memberi Peringatan

Memberi peringatan atau mengancam dalam Kamus Besar Bahasa Indonesia (KBBI) dapat ditafsirkan sebagai tindakan mengutarakan niat atau maksud untuk melaksanakan suatu hal yang membebani, menyulitkan dan menyusahkan orang lain. Sementara itu, Solan dan Tiersma mengatakan bahwa peringatan atau ancaman memberikan dasar pertanggungjawaban pidana jika menanamkan rasa takut kekerasan sebagai retribusi karena gagal memenuhi permintaan. Tindakan ancaman ini sama halnya dngan menyerang psikis dan menimbulkan rasa tidak aman terhadap orang lain. adalah salah satu wujud ujaran kebencian yang bertujuan untuk menjatuhkan, mencela, menistakan atau melecehkan seseorang. Berikut adalah tabel analisis komentar netizen Indonesia di kolom komentar Instagram Rahmawati Kekeyi Putri Cantikka yang terdeteksi mengandung ujaran kebencian peringatan:

Tabel 3 Analisis Implikatur Peringatan di Kolom Komentar Instagram @ rahmawatikekeyiputricantikka23

\begin{tabular}{|c|c|c|c|}
\hline No & Akun & Komentar & Analisis Implikatur \\
\hline & @ularsawah99 & $\begin{array}{l}\text { Jelek ya jelek aja, } \\
\text { gausah bohongin diri } \\
\text { sendiri.. introspeksi } \\
\text { diri kek, ngaca kek.. } \\
\text { STOP } \\
\text { DRAMA.. } \\
\text { STOOOOOOOOPID }\end{array}$ & $\begin{array}{l}\text { Komentar "Jelek ya jelek } \\
\text { aja, gausah bohongin diri } \\
\text { sendiri.. introspeksi diri } \\
\text { kek, ngaca kek.. STOP } \\
\text { THIS } \quad \text { DRAMA... } \\
\text { STOOOOOOOOPID" pada } \\
\text { ujaran disamping } \\
\text { teridentifikasi sebagai } \\
\text { ujaran kebencian memberi } \\
\text { peringatan. Penutur } \\
\text { memperingatkan Kekeyi } \\
\text { agar berhenti mencari } \\
\text { perhatian di media sosial } \\
\text { instagram nya dengan } \\
\text { cara introspeksi diri. }\end{array}$ \\
\hline 2. & @nisswa_ & $\begin{array}{lr}\begin{array}{l}\text { Key, dulu } \\
\text { direspekin }\end{array} & \text { lu kan } \\
\text { karna }\end{array}$ & $\begin{array}{llr}\text { Komentar } & \text { "Coba } & \text { deh } \\
\text { intropeksi } & \text { diri." } & \text { pada }\end{array}$ \\
\hline
\end{tabular}




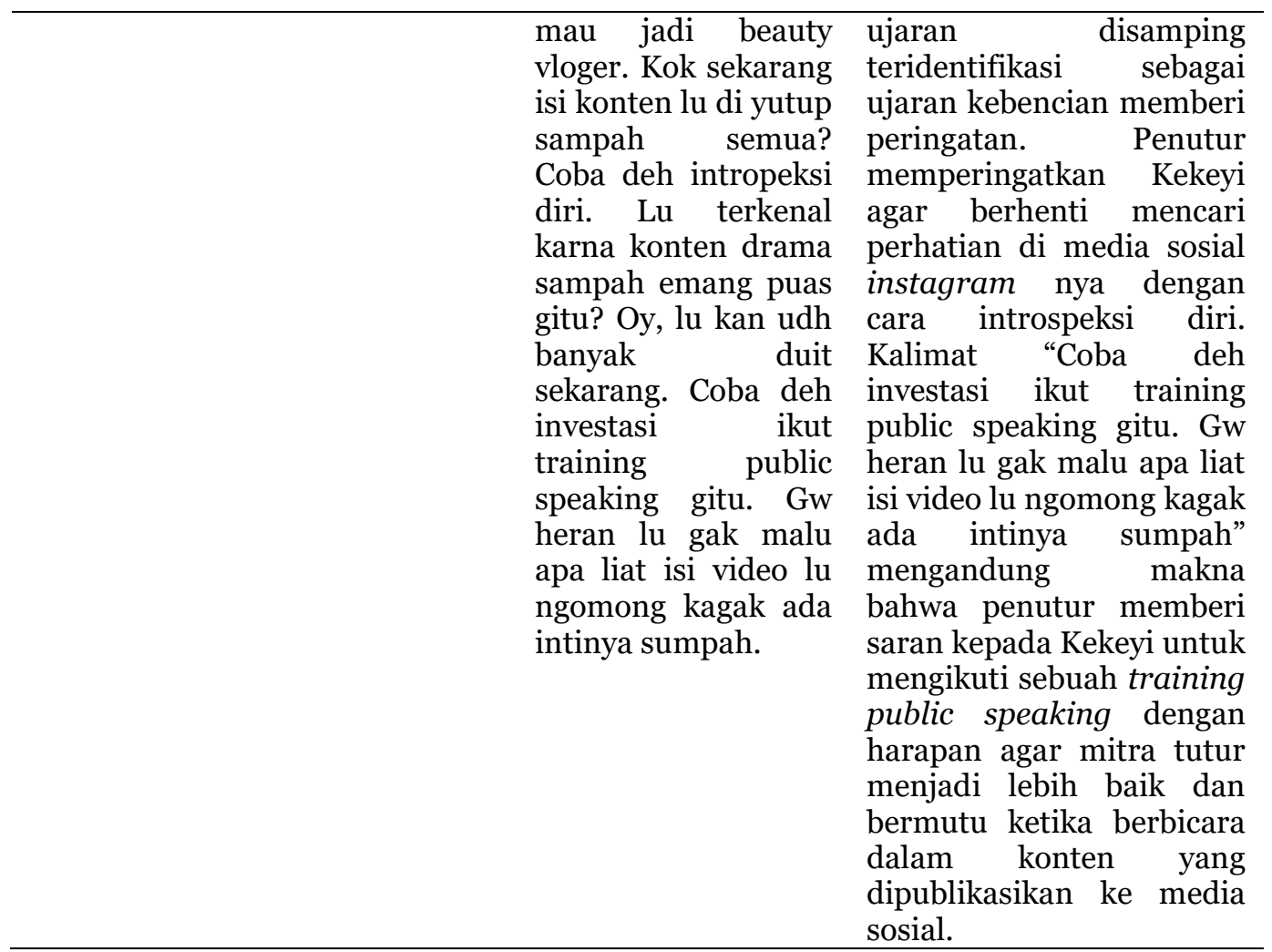

\section{Memprovokasi}

Kejahatan berbahasa bisa dilakukan dengan berbagai macam tindak tutur. Soesilo mengatakan memprovokasi atau menghasut artinya mengajak, mendorong, menumbuhkan atau membangkitkan semangat seseorang hingga melakukan sesuatu. Menghasut dapat dilakukan baik secara lisan maupun tulisan. Jika dilakukan secara lisan, maka kejahatan menjadi selesai ketika kalimat yang bersifat memprovokasi tersebut telah diucapkan. Namun, jika dilakukan secara tulisan, hasutan haruslah ditulis terlebih dahulu, kemudian disebarkan dan ditayangkan di depan publik. (Sholihatin, 2019, hlm. 52). Tindakan memprovokasi masuk dalam Pasal 160 KUHP. Berikut adalah tabel analisis komentar netizen Indonesia di kolom komentar Instagram Rahmawati Kekeyi Putri Cantikka yang terdeteksi mengandung ujaran kebencian memprovokasi:

Tabel 4 Analisis Implikatur Memprovokasi di Kolom Komentar Instagram @rahmawatikekeyiputricantikka23

\begin{tabular}{llll}
\hline No & Akun & Komentar & Analisis Implikatur \\
\hline 1. & @ai.em.o.o_emo_emo_ & YANG GA SUKA & Komentar "YANG GA SUKA \\
& & KEKEYI LIKE & KEKEYI LIKE DONK \\
& DONK & SAHABAT!" pada ujaran \\
& & SAHABAT! & disamping teridentifikasi \\
& & sebagai ujaran kebencian \\
& & memprovokasi. Like donk \\
& & sahabat! adalah frasa yang \\
\hline
\end{tabular}


Ujaran kebencian netizen Indonesia dalam kolom komentar Instagram selebgram Indonesia: Sebuah kajian linguistik forensik

\begin{tabular}{|c|c|c|}
\hline & & $\begin{array}{l}\text { menunjukkan } \\
\text { Anakan. } \\
\text { Analisis hermeneutik pada } \\
\text { komentar ini memiliki } \\
\text { makna bahwa netizen } \\
\text { tersebut mengajak netizen } \\
\text { lainnya untuk menyukai } \\
\text { komentarnya, dia berusaha } \\
\text { untuk membangkitkan } \\
\text { kebencian netizen lain } \\
\text { terhadap Kekeyi. }\end{array}$ \\
\hline 2. @obywooody & $\begin{array}{lr}\text { Yg tadinya } & \text { suka } \\
\text { sama kak miko, } \\
\text { eh pas tau } \\
\text { temenan } \text { sama } \\
\text { kekeyi } \quad \text { kok } \\
\text { seketika jadi jijik } \\
\text { ya }\end{array}$ & $\begin{array}{l}\text { Komentar "Yg tadinya suka } \\
\text { sama kak miko, eh pas tau } \\
\text { temenan sama kekeyi kok } \\
\text { seketika jadi jijik ya" pada } \\
\text { ujaran disamping } \\
\text { teridentifikasi sebagai ujaran } \\
\text { kebencian memprovokasi. } \\
\text { Seketika pada jijik ya adalah } \\
\text { frasa yang menunjukkan } \\
\text { ajakan untuk menghadirkan } \\
\text { kepada netizen lainnya rasa } \\
\text { yang sama dengan yang } \\
\text { sedang dirasakannya. } \\
\text { Analisis hermeneutik pada } \\
\text { komentar ini memiliki } \\
\text { makna bahwa netizen } \\
\text { tersebut mengajak netizen } \\
\text { lainnya yang sebelumnya } \\
\text { merupakan fans dari } \\
\text { seorang selebgram bernama } \\
\text { Miko untuk tidak lagi } \\
\text { menyukai Miko karena ia } \\
\text { berteman dengan Kekeyi. } \\
\text { Komentar ini memprovokasi } \\
\text { para netizen untuk } \\
\text { menghujat Kekeyi karena } \\
\text { pertemanannya dengan } \\
\text { Miko dapat menghancurkan } \\
\text { reputasi dan image Miko } \\
\text { menjadi buruk. }\end{array}$ \\
\hline
\end{tabular}

Secara umum berikut ini adalah implikatur ujaran kebencian netizen Indonesia di kolom komentar Instagram Kekeyi:

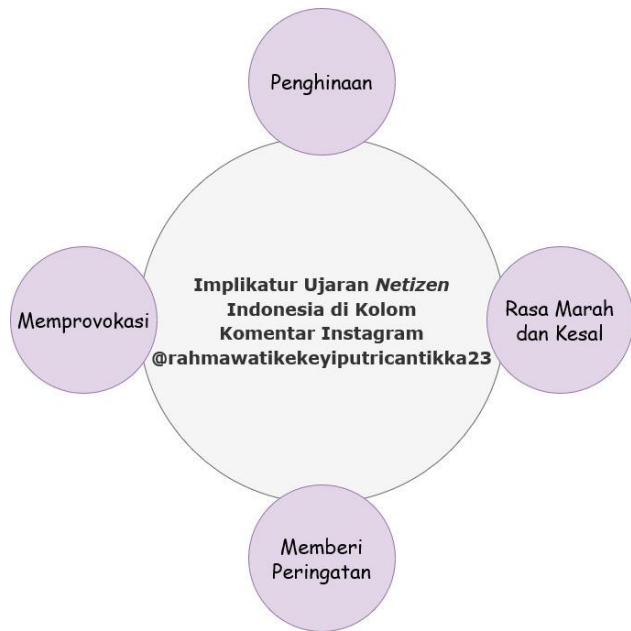

Gambar 1 Analisis Implikatur Ujaran Kebencian Netizen Indonesia di Kolom Komentar Instagram @rahmawatikekeyiputricantikka23 
Dengan demikian, setelah melakukan analisis terhadap implikatur ujaran netizen Indonesia di kolom komentar akun Instagram Selebgram Indonesia ini, peneliti menemukan terkandung empat implikatur diantaranya adalah: (1) Implikatur ingin menghina dan menghujat, hal ini dilihat dari netizen yang cenderung ingin mengumbar keburukan dan kejelekan, hingga aib yang dimiliki mitra tutur di muka umum supaya mitra tutur merasa malu dan insecure terhadap dirinya sendiri, (2) Implikatur merasa kesal dan marah, (3) Implikatur ingin memberi peringatan, dalam hal ini para netizen berusaha menperingatkan kekeyi agar tidak melakukan suatu perbuatan yang negatif seperti yang dituduhkan netizen, (4) Implikatur ingin memprovokasi, yaitu netizen bermaksud untuk mempengaruhi netizen lainnya agar sepemikiran dengannya.

\section{Daya Ilokusi Ujaran Netizen Indonesia di Kolom Komentar Instagram Selebgram Indonesia}

Austin mengatakan bahwa ketika seseorang sedang mengutarakan suatu ujaran, ia tidak hanya menginformasikan sesuatu. Akan tetapi, disaat yang sama dia juga sedang melakukan sesuatu, misalnya berjanji, melarang, bahkan menghina. Sebuah ujaran berwujud tulisan status atau komentar di media sosial juga dapat menjadi sebuah tindakan, misalnya menghina, menghujat, membohongi, hingga menghasut seseorang.

Searle menambahkan bahwa tindak tutur bukanlah hanya mengenai ujaran apa yang disampaikan oleh seseorang (ilokusi), melainkan apa yang ada dibalik ujaran tersebut. Ilokusi adalah apa yang sedang dilakukan oleh seseorang itu ketika menyampaikan suatu ujaran. Searle membagi tindak tutur (daya ilokusi) sesuai dengan kategorisasi fungsi menurut nilai komunikatifnya sebagai berikut: (1) asertif, yaitu tuturan yang mengikat penutur terhadap kebenaran proposisi yang diucapkan, seperti menegaskan, menyatakan, mengeluh, membual, menyarankan dan mengemukakan pendapat; (2) direktif, yaitu tuturan yang dimaksudkan untuk memberikan pengaruh terhadap pendengar atau mitra tutur, seperti memerintah, memberi nasehat, merekomendasikan, dan memohon; (3) komisif, yaitu fungsi yang mengikat penuturnya berkomitmen untuk melakukan apa yang diujarkannya di masa depan, seperti menawarkan bantuan, berjanji, bersumpah, menjamin, menolak, dan mengancam; (4) ekspresif, yaitu fungsi untuk menyatakan sikap dan perasaan seorang penutur terhadap suatu situasi tertentu atau reaksi terhadap sikap dan perbuatan seseorang, seperti memberi selamat, meminta maaf, menyesali perbuatan, bersyukur, menyambut, dan berterimakasih; (5) deklaratif, yaitu ilokusi yang menimbulkan perubahan atau kesesuaian antara 
proposisi dan realitas, seperti memecat, memberi nama, membaptis, dan menghukum.

Berdasarkan penelitian yang dilakukan dengan mengumpulkan data dari kolom komentar instagram pada akun@ @rahmawatikekeyiputricantikka23 secara acak, peneliti memperoleh data yang telah dianalisis tindak tutur ilokusinya. Daya ilokusi ini mengandung maksud tuturan, berkaitan dengan siapa bertutur, dan kepada siapa, kapan dan dimana tindak tutur dilakukan, dan lain sebagainya. Beberapa tuturan netizen yang dapat dianalisis tindak ilokusinya dalam kolom komentar instagram @ rahmawatikekeyiputricantikka23, diantaranya sebagai berikut:

\section{Tabel 5 Analisis Daya Ilokusi Ujaran Netizen Indonesia di Kolom Komentar Instagram @rahmawatikekeyiputricantikka23}

\begin{tabular}{|c|c|c|c|}
\hline No & Data & Konteks Tindak Tutur & Daya Ilokusi \\
\hline 1. & $\begin{array}{lr} & \text { "SALATU } \\
\text { MAKHLUK LANGKA } \\
\text { YG PLING } & \text { WAJIB } \\
\text { DIKUBUR!”. } & \\
\text { @akbarhaha_- }\end{array}$ & $\begin{array}{l}\text { Analisis tindak tutur dalam segi } \\
\text { ilokusi pada komentar disamping } \\
\text { dapat ditemukan dalam frasa } \\
\text { "PLING WAJIB DIKUBUR!" } \\
\text { mengandung makna netizen sebagai } \\
\text { penutur menegaskan kepada netizen } \\
\text { lainnya bahwa Kekeyi adalah salah } \\
\text { satu makhluk langka yang paling } \\
\text { wajib dikubur. }\end{array}$ & Asertif. \\
\hline 2. & $\begin{array}{l}\text { "KEKEYI HAMIL } \\
\text { SEBELUM } \\
\text { LEBARAN". } \\
\text { @arthurrespati }\end{array}$ & $\begin{array}{l}\text { Analisis tindak tutur dalam segi } \\
\text { ilokusi pada komentar disamping } \\
\text { dapat ditemukan dalam kalimat } \\
\text { "KEKEYI HAMIL SEBELUM } \\
\text { LEBARAN" mengandung arti bahwa } \\
\text { netizen menuduh bahwa Kekeyi } \\
\text { telah hamil sejak sebelum lebaran. } \\
\text { Karena pernyataan ini belum dapat } \\
\text { dibuktikan kebenarannya maka bisa } \\
\text { termasuk ilokusi menuduh dan } \\
\text { pencemaran nama baik. }\end{array}$ & Asertif. \\
\hline 3 . & $\begin{array}{l}\text { "Giginya jgn dimajuin } \\
\text { trus sahabat”. } \\
\text { @putteeeyyy_- }\end{array}$ & $\begin{array}{l}\text { Analisis tindak tutur dalam segi } \\
\text { ilokusi pada komentar disamping } \\
\text { dapat ditemukan dalam frasa "jgn } \\
\text { dimajuin trus" mengandung arti } \\
\text { bahwa seorang netizen melarang } \\
\text { Kekeyi untuk berpose dengan } \\
\text { memajukan giginya. Hal ini berarti } \\
\text { penutur menilai bentuk fisik mitra } \\
\text { tutur dengan kategori yang negatif. }\end{array}$ & Deklaratif. \\
\hline 4. & $\begin{array}{l}\text { "Mba ada niatan buat } \\
\text { di behel gak? Ngeri } \\
\text { liat gusi sama gigi nya } \\
\text { ampun”. } \\
\text { @miaaf.a }\end{array}$ & $\begin{array}{l}\text { Analisis tindak tutur dalam segi } \\
\text { ilokusi pada komentar disamping } \\
\text { dapat ditemukan dalam frasa “"Mba } \\
\text { ada niatan buat di behel gak?” } \\
\text { mengandung arti bahwa seorang } \\
\text { netizen menyatakan dalam bentuk } \\
\text { pertanyaan apakah mitra tutur } \\
\text { mempunyai niat untuk memaka } \\
\text { behel, karena munculnya faktor dari }\end{array}$ & $\begin{array}{l}\text { Deklaratif } \\
\text { ekspresif. }\end{array}$ \\
\hline
\end{tabular}




\begin{tabular}{|c|c|c|c|c|}
\hline & & $\begin{array}{l}\text { si penutur yang merasa ngeri } \\
\text { melihat gusi dan gigi mitra tutur } \\
\text { dalam postingan yang diunggahnya. } \\
\text { Hal ini terlihat dalam frasa "Ngeri } \\
\text { liat gusi sama gigi nya ampun". }\end{array}$ & & \\
\hline 5. & $\begin{array}{l}\text { "Key bisa ga sih jngan } \\
\text { berulah, malu dong } \\
\text { umur loh dah } 25 \\
\text { kelakuan kya ank bru } \\
\text { puber, lu di bully } \\
\text { netizen bknx } \\
\text { memperbaiki diri } \\
\text { malah tambah parah". } \\
\text { @nir_wana040302 }\end{array}$ & $\begin{array}{l}\text { Analisis tindak tutur dalam segi } \\
\text { ilokusi pada komentar disamping } \\
\text { dapat ditemukan dalam frasa "Key } \\
\text { bisa ga sih jngan berulah, malu dong } \\
\text { umur loh dah } 25 \text { kelakuan kya ank } \\
\text { bru puber" yang mengandung arti } \\
\text { bahwa si penutur menyarankan agar } \\
\text { mitra tutur tidak lagi mengulangi } \\
\text { perbuatannya lagi. Pada frasa "lu di } \\
\text { bully netizen bknx memperbaiki diri } \\
\text { malah tambah parah" memiliki arti } \\
\text { bahwa penutur mengeluhkan sikap } \\
\text { mitra tutur yang malah semakin } \\
\text { parah walaupun sudah di bully oleh } \\
\text { netizen. }\end{array}$ & Asertif. & \\
\hline 6. & $\begin{array}{l}\text { "Keyy tolong yaa aku } \\
\text { lagi hamil, dirimu } \\
\text { jangan kluar di } \\
\text { beranda aku trus". } \\
\text { @rikapranataa_ }\end{array}$ & $\begin{array}{l}\text { Analisis tindak tutur dalam segi } \\
\text { ilokusi pada komentar disamping } \\
\text { dapat ditemukan dalam kalimat } \\
\text { "Keyy tolong yaa aku lagi hamil, } \\
\text { dirimu jangan kluar di beranda aku } \\
\text { trus" mengandung arti bahwa } \\
\text { seorang penutur memberi ancaman } \\
\text { dan meminta bantuan kepada } \\
\text { Kekeyi untuk tidak muncul di } \\
\text { beranda Instagram sang penutur } \\
\text { karena ia sedang hamil. Kalimat ini } \\
\text { juga dapat bermakna sindiran untuk } \\
\text { mitra tutur. }\end{array}$ & Komisif. & \\
\hline 7. & $\begin{array}{l}\text { "Makasih yang udah } \\
\text { ngehujattt. Komen2 lu } \\
\text { mewakilkan gw bro. } \\
\text { Gw gengsi ngehujat ni } \\
\text { orang". } \\
\text { @sa.nders56 }\end{array}$ & $\begin{array}{l}\text { Analisis tindak tutur dalam segi } \\
\text { ilokusi pada komentar disamping } \\
\text { dapat ditemukan dalam frasa } \\
\text { "Makasih yang udah ngehujattt" } \\
\text { memiliki arti bahwa seorang } \\
\text { penutur berterimakasih kepada para } \\
\text { mitra tutur yang telah berkomentar } \\
\text { dengan menghujat Kekeyi di kolom } \\
\text { komentar Instagram. }\end{array}$ & Ekspresif. & \\
\hline 8. & $\begin{array}{l}\text { "Sebagai manusia yg } \\
\text { mukanya sama2 } \\
\text { dibawah standar, aku } \\
\text { saranin lebih baik } \\
\text { bersikap biasa aja, ga } \\
\text { usah dijelek2in karna } \\
\text { emang udah :') over } \\
\text { PD upload beginian } \\
\text { mulu di IG bikin } \\
\text { Gedeg orang, nanti } \\
\text { kamu dosa". } \\
\text { @aboutfakh }\end{array}$ & $\begin{array}{l}\text { Analisis tindak tutur dalam segi } \\
\text { ilokusi pada komentar disamping } \\
\text { dapat ditemukan dalam frasa "aku } \\
\text { saranin lebih baik bersikap biasa } \\
\text { aja" yang mengandung arti bahwa si } \\
\text { penutur menyarankan agar mitra } \\
\text { tutur dapat mengubah sikapnya } \\
\text { menjadi lebih baik, ditambahkan } \\
\text { dengan kalimat "over PD upload } \\
\text { beginian mulu di IG bikin Gedeg } \\
\text { orang, nanti kamu dosa" memiliki } \\
\text { arti si penutur mengancam dengan } \\
\text { mengatakan jika Kekeyi terus- } \\
\text { terusan bersikap demikian maka } \\
\text { akan membuat orang-orang kesal } \\
\text { dan marah yang akhirnya Kekeyi }\end{array}$ & $\begin{array}{l}\text { Asertif } \\
\text { komisif. }\end{array}$ & dan \\
\hline
\end{tabular}




\begin{tabular}{|c|c|}
\hline & $\begin{array}{l}\text { akan mendapat dosa akibat } \\
\text { sikapnya. }\end{array}$ \\
\hline $\begin{array}{ll}\text { 9. } & \text { "KEY BISA GA SIH } \\
\text { LO MENGHILANG } \\
\text { DARI MUKA BUMI } \\
\text { INI? GA } \text { USAH } \\
\text { SOK2AN } \\
\text { MENGHIBUR } \\
\text { NETIZEN. ASAL LU } \\
\text { TAU } & \text { AJA } \\
\text { MAYORITAS DARI } \\
\text { FOLLOWERS LU ITU } \\
\text { CUMA } & \text { PENGEN } \\
\text { NGEBULLY LU AJA, } & \text { LU AJA } \\
\text { BUKAN } & \text { KARENA } \\
\text { MEREKA } & \text { SUKA } \\
\text { SAMA LU BEGEE". } & \text { @lalalaa.festt }\end{array}$ & $\begin{array}{l}\text { Analisis tindak tutur dalam segi } \\
\text { ilokusi pada komentar disamping } \\
\text { dapat ditemukan dalam frasa "KEY } \\
\text { BISA GA SIH LO MENGHILANG } \\
\text { DARI MUKA BUMI INI?" } \\
\text { mengandung arti bahwa seorang } \\
\text { netizen menyatakan dalam bentuk } \\
\text { pertanyaan apakah mitra tutur } \\
\text { mempunyai niat untuk menghilang } \\
\text { dari muka bumi, jika disesuaikan } \\
\text { dengan konteks maka yang } \\
\text { dimaksud adalah menghilang dari } \\
\text { kehidupan si penutur. }\end{array}$ \\
\hline
\end{tabular}

Dengan demikian, secara umum ujaran netizen Indonesia di kolom komentar Instagram Selebgram Indonesia berdimensi tindakan, diantaranya sebagai berikut: (1) Menyindir disertai dengan olokan keburukan dan aib mitra tutur di muka publik. Sindiran tersebut ditandai dengan penggunaan kalimat pertanyaan atau interogatif yang menumbuhkan nilai rasa atau konotasi negatif dalam situasi ironis (menyindir) dengan tujuan menjatuhkan dan membuat malu mitra tutur dimuka publik. Maksud ingin mengolok ditandai dengan penggunaan emotikon tertawa sambil menangis atau menjulurkan lidah, (2) Menuduh suatu hal atau perbuatan. Hasil analisis menunjukkan paling banyak hal atau perbuatan yang dituduhkan merupakan tindakan negatif dan memalukan. Tuduhan tersebut hanya semata-mata berlandaskan asumsi atau isi belaka dan tidak disertai dengan bukti yang memadai. Sebagai contoh komentar adalah "hamil di luar nikah", dll, (3) Mengecam tindakan mitra tutur dengan memperingatkan atas tindakan mitra tutur yang belum terbukti benarbenar terjadi, dan (4) Menilai bentuk fisik dan sifat lawan tutur dengan kategori negatif. Hal ini ditandai dengan penggunaan kata sifat adjektiva atau kata julukan negatif.

\section{Tingkat Validitas Ujaran Netizen Indonesia di Kolom Komentar Instagram Selebgram Indonesia yang diduga merupakan Ujaran Kebencian}

Semua tentang komunikasi adalah semua tentang bahasa, karena bahasa itu sendiri adalah alat berkomunikasi. Adapun peristiwa komunikasi bahasa secara umum dibedakan menjadi penyampaian fakta dan penyampaian gagasan. Penyampaian fakta merupakan peristiwa menyampaikan apa yang diserap, apa yang dilihat, apa yang didengar, apa yang dicium, apa yang diucap dan apa yang diraba oleh panca indra. Sedangkan penyampaian gagasan merupakan 
peristiwa penyampaian pendapat, pesan, komentar, kesimpulan, masalah, pemecahan masalah, dan lain sebagainya. (Endraswara, 2010, hlm. 1).

Austin menerangkan terdapat beberapa syarat validitas yang digunakan untuk mengukur tingkat validitas tuturan performatif, dintaranya yaitu: (1) Ditandai dengan verba present (bukan masa lampau), (2) Orang yang mengatakan memiliki niat yang kuat untuk melakukan apa yang dikatakannya, (3) Orang yang mengatakan memiliki kepatutan atau relevansi dengan apa yang dikatakannya. Teori Austin tersebut berkaitan dengan penelitian ini dalam aspek syarat-syarat validitas yang digunakan untuk mengukur dan membuktikan validitas tuturan para netizen Instagram dalam berkomentar yang diduga sebagai makian dan ujaran kebencian. Gagasan Austin diterapkan untuk semua tindak tutur performatif. Penelitian ini berfokus pada tindak tutur kebencian. Oleh karena itu, peneliti ini dilandasi gagasan Austin (felicity condition) untuk merumuskan syarat-syarat dalam tindak tutur makian atau ujaran kebencian yang harus dipenuhi agar tindakan melalui tuturan tersebut dapat dikatakan valid.

Berlandaskan pada hasil analisis menggunakan validitas tuturan dapat diketahui bahwa netizen mempunyai hak untuk mengutarakan kebencian jika merasa marah, kesal, benci, prihatin ataupun emosi lainnya yang serupa. Dalam hal ini terdapat kesesuaian antara yang dilakukan penutur dengan kondisi yang melatarinya. Dilihat dari hasil analisis terhadap implikatur ujaran netizen mengungkapkan ujaran kebencian dengan kesungguhan. Sebagian besar netizen Indonesia menuturkan ujaran kebencian disebabkan karena ingin mengekspresikan emosinya, baik rasa marah, kesal, benci ataupun emosi lainnya atas tindakan mitra tutur yang belum terbukti kebenarannya. Ujaran netizen Indonesia di kolom instagram Kekeyi juga berdimensi tindakan dengan mengategorikan lawan tutur pada sesuatu yang buruk dan negatif, yaitu menyindir dengan mengolok-olok keburukan dan aib mitra tutur agar ia merasa malu. Berdasarkan analisis terhadap tingkat validitas, terdapat 15 ujaran netizen dari 22 data dikatakan valid untuk kemudian dinyatakan sebagai ujaran kebencian, seperti yang dinyatakan dalam pasal 27 ayat (3) juncto Pasal 45 ayat (1) UU RI No. 9/2016 tentang Pembatasan UU Nomor 11 Tahun 2008 mengenai Informasi dan Transaksi Elektronik(ITE).

\section{Kesimpulan}

Berlandaskan pada hasil penelitian, maka dapat diambil kesimpulan bahwa terdapat empat implikatur diantaranya: (1) Implikatur ingin menghina dan menghujat, (2) Implikatur merasa kesal dan marah, (3) Implikatur ingin memberi peringatan, dan (4) Implikatur ingin memprovokasi. Secara umum ujaran netizen Indonesia pada kolom komentar Instagram Selebgram Indonesia berdimensi tindakan, diantaranya: (1) Menyindir disertai dengan olokan keburukan dan aib mitra tutur dimuka publik, (2) Menuduh suatu hal atau 
perbuatan, (3) Mengecam tindakan mitra tutur dengan memperingatkan atas tindakan mitra tutur yang belum terbukti benar-benar terjadi, dan (4) Menilai bentuk fisik dan sifat lawan tutur dengan kategori yang negatif. Hal ini ditandai dengan penggunaan kata sifat adjektiva atau kata julukan negatif. Berdasarkan analisis terhadap tingkat validitas, terdapat 15 ujaran netizen dari 22 data dapat dikatakan valid untuk kemudian dinyatakan sebagai ujaran kebencian, seperti yang dinyatakan dalam pasal 27 ayat (3) juncto Pasal 45 ayat (1) UU RI No. 9/2016 tentang Pembatasan UU Nomor 11 Tahun 2008 mengenai Informasi dan Transaksi Elektronik (ITE). Hasil dari penelitian ini sangat diharapkan dapat dijadikan sebagai rujukan dan tambahan pengetahuan bagi masyarakat Indonesia, terlebih lagi para konsumen media sosial supaya menjadi lebih bijak ketika berbicara di dunia maya. Adapun keterbatasan dalam penelitian ini adalah objek penelitian hanya berfokus pada salah satu sosial media saja, yaitu Instagram.

\section{Daftar rujukan}

Bank, J. (2011). Regulating hate speech online. International Review of Law, Computers \& Technology, 24(3).

Endraswara, S. (2010). Metodologi penelitian sastra. Yogyakarta: Media Pressindo.

Koncavar, A. (2013). Hate speech in new media. Academic Journal of Interdisciplinary Studies, 2(8).

Ningrum, D. J., Suryadi, \& Wardhana, D. E. C. (n.d.). Kajian ujaran kebencian di media sosial. Jurnal Ilmiah KORPUS, III.

Olsson, J. (2008). Forensic linguistics: second edition. London: Cobtinum International Publishing Group.

Sholihatin, E. (2019). Linguistik forensik dan kejahatan berbahasa (Cetakan 1; N. Haryono, ed.). Yogyakarta: Pustaka Pelajar.

Syarif, E. (2019). Pengaruh media sosial terhadap sikap dan pendapat pemuda mengenai ujaran kebencian. Jurnal Common, 3(2). 